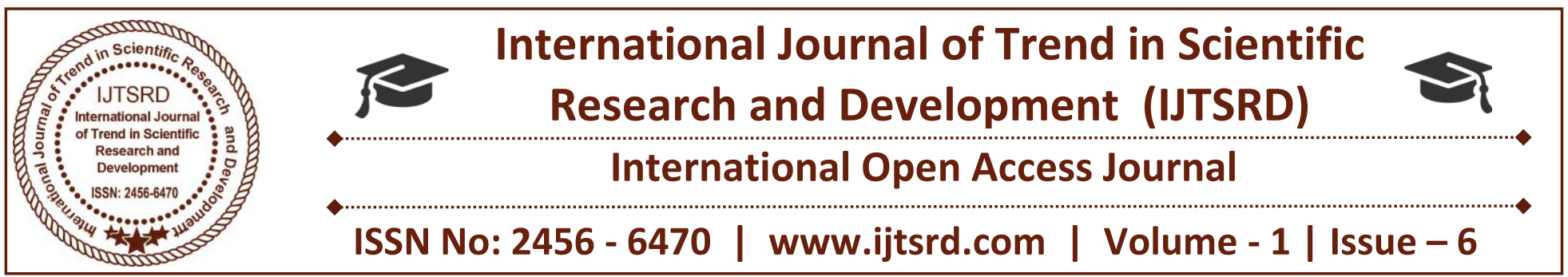

\title{
Dogra Rule: State of Jammu and Kashmir (1846-1952)
}

\author{
Dr. Syed Damsaz Ali Andrabi \\ College Teacher, History, Department of Higher Education, J\&K
}

\section{ABSTRACT}

The occupation of Kashmir by Gulab Singh on 1846, was a landmark in the socio-religious and cultural history. As for the first time the state of Jammu and Kashmir is having its own identity provided by the treaty of Amritsar. But the intervention of foreign elements as British proved very harmful for Kashmiris. Nodoubt different developmental measures were taken, but actually they were taken to fulfill their own pockets. Kashmir as such was very rich in resources but every time were exploited by them for their personal benefits. Harsh taxation policy resulted in the migration of artisans towards other areas. Each and every industry was at first instance patronized but later on was put under the burden of illegal taxes. The revenue earned activities of arts and crafts for which Kashmir valley was famous were completely ruined. Skilled section cut their fingers and thumbs in order to have disability. Whatever was earned was taken forcibly and were left with the mercy of God. People raised their voice against the atrocities of Dogras that resulted in mascare of innocents

Keywords: Occupation, Illiteracy, Harsh Taxation, Illegalities

\section{INTRODUCTION}

The Jammu and Kashmir state came in to existence in 1846, under the treaty of Amritsar signed between the Maharaja Gulab Singh on the one hand and the British Government on the other side, after the first AngloSikh war of,1845-46, and Maharaja Gulab Singh ${ }^{1}$ was nominated as its first ruler. On the eve of, 1846 Kashmir, Jammu as well as Ladakh were under the control of Lahore Darbar of Sikh Kingdom, while as
Kashmir was ruled by a Subedar deputed by the Lahore Darbar. Jammu and Ladakh were under a Jammu Dogra, Gulab Singh, who too was under the dominance of Lahore Darbar. The three distinctive geographical, cultural and political entities namely Kashmir valley, Jammu and Ladakh were merged into one political entity for the first time in history. The territories of the state had constituted a part of the Sikh Kingdom and being ruled by different dynasties at different time's .It is only the valley of Kashmir which has retained the position of an empire the position it enjoyed for centuries together. On the contrary Jammu and Ladakh regions were fragmented into petty states, each under a local potentate.

The colonial expansion policy had a direct bearing on the political situation of Jammu, Kashmir and Ladakh. The Britishers had a covetous eye on Punjab which led Anglo-Sikh wars. Since Gulab Singh was a very influential member of Lahore darbar. The Britishers in a bit to create defection among the Sikh generals to ensure their success and succeeded in wooing in Gulab Singh to their side. This proved fatal for the Sikhs and Punjab fell in the hands of the Britishers. At the end of the war a treaty known as treaty of Lahore was concluded on $9^{\text {th }}$ March 1846, between the British Government and the Darbar of Sikhs at Lahore ${ }^{2}$ under which Jammu, Kashmir and Ladakh regions were snatched away from the Sikhs. On $16^{\text {th }}$ March 1846 another treaty commonly known as Treaty of Amritsar was concluded. Because the treaty was enunciated at Amritsar between the British Government and the Maharaja Gulab Singh of Jammu who until the conclusion of the war was a feudatory of the Sikhs, by virtue of the aforementioned treaty, Jammu, Kashmir and Ladakh were transferred to 
Gulab $^{3}$ Singh. After the treaty Gulab Singh received the legal title over the territories but not their possession that the company itself have only, the part that he held earlier as a feudatory of Sikh sovereign was under his actual control. The rest had to be consolidated by Gulab Singh himself. In the process, exchange of certain territories was made with the mediation of the British government. The British aid and assistance was also sought to redeem Kashmir from the Sikh Nazim, Sheikh Imamu'd-din, who was resisting its occupation. The British intervention put an end to this and led to the return of Sikhs from Srinagar on 23 October, 1846. Gulab Singh entered Kashmir as the first Dogra Maharaja of the state on 1st November 1846.Contrary to general belief that the state was not an independent one, for independence, unlike sovereignty, cannot be divided. The various articles in the treaty are sufficiently supporting the fact that Gulab Singh accepted the supremacy of the British government. Nor was it a feudatory, a status to which it was reduced later in 1860. Jurisdically, it was a sovereign state and certain restrictions were put on its external sovereignty otherwise, it was left autonomous. This is what K.M Panikkar, rightly conveys when he uses the expression "totally independent in its internal affairs". No control was exercised by the British government in the administration and no resident was appointed till, 1885. In fact the political position in the Punjab has not made any such intervention impossible at that crucial juncture.

The state was not a personnel creation of Gulab Singh but was rather the outcome of an agreement between him and the representatives of the British East India Company. The prospect for such an eventuality was first envisaged in the treaty that laid down the terms for the conclusion of first Anglo-Sikh ${ }^{4}$ war 1845. The agreement stipulated the creation of a new state by transferring the territories between the River Ravi and Indus and makes over for ever independent possession to Gulab Singh and his natural male ${ }^{5}$ descendents. In return Gulab Singh agreed to pay the British ${ }^{6}$ Government 75, lakhs of rupees (Nanak Shahi). The momentous decision was to serve the colonial interests of the British government. Undoubtly the J\&K state was strategically a very important state considering the un-pending threat of Russia and China. But to maintain this state at that crucial juncture was very expensive, because of the absence of effective means of communication to keep a hold over the state. Therefore, Lord Harding found it politically unwise and militarily impossible to maintain grip on the administrative measures of state Jammu and Kashmir ${ }^{7}$. At the same time, he also found it necessary to snatch it from the $\mathrm{Sikhs}^{8}$ to reduce their position to a weaker level . There was no local ruling family with which any arrangement could be made. In fact there had existed none after its annexation by the Great Mughals in 1586. It was fully recognized policy of the British government then not to have a Muslim political power on this side of the Indus ${ }^{9}$. Evidently it was the immediate need of the British imperial interests in 1846 and not Gulab Singhs perfidy towards his masters, as F.M. Hassnain believes ${ }^{10}$, which dictated that Kashmir be juxtaposed with its adjoining territories to form the new state. Therefore the Britishers thought it better to hand over it to a loyalist who would rule over the state on their behalf, so that two purposes would be simultaneously served. One that a buffer state would be created to save the British India from the Russian and Chinese advancements and secondly they would not have to made any investigations of it, as it was not possible for them to do it in the then given financial conditions. Since Gulab Singh had proved loyal to them during their struggle to annex Punjab, it was thought better to hand over the state to him. At the time of treaty of Amritsar the Britishers had some misunderstanding regarding Russian and Chinese advancements and as well as economic potential of the state. They had probably not realised the much needed control over the state in relation to Russian and Chinese forward policy. Because after a short time we find them on keeping a control over the Kashmir when Russia was making rapid advances in Central Asia. From the statements of British diplomats and opinion makers it seems that they had realised the folly of surrendering the state to Gulab Singh immediately after the signing of treaty. That is why they subsequently, compelled the Maharaja to accept the British person as an officer on special duty in Kashmir, actually an agent at Gilgit and subsequently in 1885, they appointed a British Resident. Another important reason which compelled the British government to bestow the emblem of sovereignty on Gulab Singh was primarily to weaken the Sikhs by driving a permanent wedge between them and the Dogra Rajput ${ }^{11}$ of the hills. A policy that had been toyed with by the British ${ }^{12}$ decision makers earlier. This had now become an urgent necessity because the $\mathrm{Sikh}^{13}$ army though defeated in the war had proved itself too strong to be completely beaten 
and the British found it difficult to annex Punjab immediately.

\section{Provisions of the Treaty}

The British Government has demanded from the Lahore, as indemnification for the war expenses. The payment of one and a half crore of rupees and the Lahore government being unable to pay the whole of sum at this time, or to give security satisfactory to the British government for its eventual payment. The Maharaja cedes to the Company in perpetual sovereignty, as equivalent for one crore of rupees, all his forts, territories, rights and interests, which are situated between the rivers Beas and Indus, including the provinces of Kashmir and Hazara. In consideration of the services rendered by Raja Gulab Singh of Jammu to the Lahore state, towards procuring the restoration of the relations of amity between the Lahore and British government, the Maharaja hereby agrees to recognize the independent sovereignty of Raja Gulab Singh, in such territories and districts in the hills as may be made over to the Raja Gulab Singh by separate agreement between him and the British Government, with the dependencies, thereof, which may have been in the Raja's possession since the time of the late Maharaja Kharrak Singh and the British Government, in consideration of the good conduct of Raja Gulab Singh, also agrees to recognize his independence in such territories and admit him to the privileges of a separate treaty with the British government.

Article: i, The British Government transfers and makes over, forever in independent possession, to Maharaja Gulab Singh and heir males of his body, all the hilly or mountainous country, with its dependencies situated to the Eastward of the river, Indus and Westward of the river Ravi, including Chamba and excluding Lahol, being part of the territories ceded to the British government by the Lahore Darbar .

Article: ii, The Eastern boundary of the tract transferred by the foregoing Article to Maharaja Gulab Singh shall be laid down by commissioners appointed by the British government and Maharaja Gulab Singh respectively for that purpose and shall be defined in a separate engagement after survey.

Article: iii, In consideration of the transfer made to him and his heirs by the provisions of the foregoing Articles, Maharaja Gulab Singh will pay to the British Government the sum of seventy five lakhs of rupees
(Nanakshahi), fifty Lakhs to be paid on ratification of this treaty and twenty-five lakhs on or before the 1st October of the current year, 1846 A.D.

Article: iv, The limits of the territories of Maharaja Gulab Singh shall not be at any time changed without the concurrence of the British Government.

Article: v, Maharaja Gulab Singh will refer to the arbitration of the British government any disputes or questions that may arise between him and the government of the Lahore or any other neighbouring state and will abide by the decision of the British government.

Article: vi, Maharaja Gulab Singh engages for himself and his heirs to join with the whole of his military forces, the British troops when employed in the hills or in the territories adjoining his possessions.

Article: vii, Maharaja Gulab Singh engages never to take or retain in his service neither any British subject nor the subject of any European or American state without the consent of the British government.

Article: viii, Maharaja Gulab Singh engages to respect, in regard to the territory transferred to him, the provisions of the Articles, v, vi, vii, of the separate engagement between the British government and the Lahore Darbar, dated, 11th March, 1846 A.D.

Article: ix, The British government will give its aid to Maharaja Gulab Singh in protecting his territories from external enemies.

Article: x, Maharaja Gulab Singh acknowledges the supremacy of the British government and will in token of such supremacy present annually to the British government one horse, twelve perfect shawl goats of approved breed (six male and six female) and three pairs of Kashmiri Shawls.

This treaty ${ }^{14}$ consisting of the above articles has been this day settled by Frederic Currie Esq. and BrevetMajor Henry Montgomery Lawrence, acting under the directions of the Right Honourable Sir Henry Harding, and by Maharaja Gulab Singh in person and the treaty has been this day ratified by the seal of the Right Honourable Sir Henry Harding, G.C.B., Governor General, done at Amritsar this sixteenth day of March in the year, 1846.A.D, corresponding with the seventeenth day Rabi-ul-Awwal 1264 Hijri.

State of Jammu and Kashmir was having the separate identity of its own. Still the overall position of 
Kashmiris under Dogras remained very hostile. No doubt some developmental measures were taken to benefit the residents by providing them security through different acts like the state subject and various others. After the death of Gulab Singh in, 1857, the later Dogra rulers showed positive attitude towards developments. Ranbir Singh, 18571885,Pratap Singh, 1885-1925,Hari Singh,1925-1949, and Karan Singh, 1949-1952,Karan Singh as Sadari Riyasat,1952-1965, and as governor, 1965-67.No doubt number of initiatives were taken to develop the economy of state and to connect Kashmir with other parts through different routes like, Banihal cart road, Jehlum valley cart road, Zojilla pass etc. Health and educational facilities were provided to people, so that they could think in terms of change. But on other side number of illegal taxes were imposed to reduce their position like medieval" Balhars". The skilled workers of famous and revenue earned industries Shawl and Silk were taxed severely. Even a Shawl weaver earns only four paisa in a day. While as the authorities used to exploit them as much they could. With the result they lost interest in their art that resulted in the downfall of art and craft centers. Besides the legalized tax on their crafts they have to pay other taxes also. Keeping in view their problems they cut their thumbs and fingers in order to have disability. They also drowned into different streams of Zaldagar Srinagar on, 1865.One can realize the cruelity of Dogra rulers through the imposition of taxes like, Revenue tax as traki, (tax on rice), shaqdar tax(grain watchers), malikana tax (paid to Maharaja as owner of land), patwari tax (related with land records), nazrana, rasum, mandri/ashgal, (construction and maintenance of temples),sathrashahi (marriage tax), rassudar(house tax), tax on graves (grave digger), zari chopan(tax on sheeps), tax on chinars (chinar leaves), plough tax, zari meva(fruit tax), rassdart (annual tax on house), horse tax, rasum(village exactions), shawl tax (tax on weavers), silk tax(tax on workers), tax on wine ,beggar (forced labour) and others etc. The taxation was so heavy that more than ninety percent of total income was snatched by Dogra ${ }^{15}$ rulers only less than ten percent was left with them. The people managed to save their life with the help of fruits. All was taxed, looks like that only air was left without taxation.

Ultimately the people of state remained silent just the cattles. As they were sold for a petty amount.As stated by G.M.D.Sufi, "each Kashmiri was thus sold for Rs.7 (seven) by a handful of British officials to Gulab Singh.
Their fields, their crops, their streams,

Even the peasants in the vale

They sold,they sold all ,alas!

How cheap was the sale!

And thus the Kashmiri became,a stranger in his own country"

To see and to understand the character of people especially of Kashmiris, it is very very difficult. On one side they will look for better profitable options and on another side they raise their voice against the administration. Actually their desires are limitless, rather uncontrolled and without proper guidance. The leaders have never tried to work for the benefit of commoners irrespective of faith. The role of leader is actually just like the head of family. Every time the masses have been deceived and the people too are equally responsible for having the tendency of resistance and that silence has ultimately shown it's result.

\section{CONCLUSION}

On the whole every one suffered a lot under the Dogra rule. With the result people raised their voices against the mismanagement that resulted in the emergence of social, political and religious movements with an aim to liberate themselves from onslaughts of Dogras.

\section{REFERENCES}

1) U.K.Zutshi, Emergence of Political Awakening in Kashmir, Ramesh Jain Publications New Delhi 1986, P.19.

2) All about Sikhs The Lahore Treaty of 1846. 'or' The British Library, India Office Records.

3) Bawa Satinder Singh, The Jammu Fox: A Biography of Maharaja Gulab Singh of Kashmir, 1792-1857.

4) Charles Viscount Harding, Viscount Harding, Oxford, 1891, p.133.

5) F.M. Hassnain, British Policy Towards Kashmir, 1846-1921.

P.17.

6) Khushwant Singh and Sarjit Singh Bal, British Policy Towards the Punjab (Calcutta, 1971), p.80.

7) Bikrama Jit Hasrat, Anglo-Sikh Relations, 17991849: A Reapraisal of the rise and Fall of the Sikhs, Hoshiarpur, 1968, pp.247-48.

8) F.M.Hassnain,British policy towards Kashmir,1974,pp.140-41. 
International Journal of Trend in Scientific Research and Development (IJTSRD) ISSN: 2456-6470

9) Administration reports of the Jammu and Kashmir state, $1872-1965$.

12) G. M.D.Sufi,Islamic

Culture

in

10) Mohammad din Fouq, Tarikhi Aqwami Kashmir,1978.pp.232-33. Kashmir,Srinagar,2007,pp.369-70.

13) G. M.D.Sufi, Kashir being a History of Kashmir, vol,ii, Srinagar, pp.766-67.

11) Mohammad Saleem Khan,Medieval Kashmir, Srinagar, 2006, pp. 232-33. 